Research Article

\title{
The Effect of First-Year Seminar Classroom Design on Social Integration and Retention of STEM First-Time, Full-Time College Freshmen
}

\author{
Miriam Leary $\mathbb{D}^{D}$, Alexander Tylka, Victoria Corsi, and Randy Bryner \\ Division of Exercise Physiology, Department of Human Performance and Applied Exercise Science, School of Medicine, \\ West Virginia University, P.O. Box 9227, Morgantown, WV 26506-9225, USA
}

Correspondence should be addressed to Miriam Leary; miriam.leary@hsc.wvu.edu

Received 14 June 2021; Accepted 17 July 2021; Published 27 July 2021

Academic Editor: Gwo-Jen Hwang

Copyright (C) 2021 Miriam Leary et al. This is an open access article distributed under the Creative Commons Attribution License, which permits unrestricted use, distribution, and reproduction in any medium, provided the original work is properly cited.

Classroom design is related to student satisfaction and learning, but its effect on student retention is unknown. This exploratory study compared the impact of classroom design on social integration and retention among STEM first-time, full-time college freshmen in a first-year seminar course by comparing classroom sizes (large (LL) vs. small (SL) lecture), classroom formats (lecture (SL) vs. flipped classroom (FC)), and classroom student composition of students at risk of attrition based on low math placement scores (combined low math (CLM) vs. separated low math (SLM)). To capture social integration of freshman after their first semester, students completed a survey for course credit. Retention rates of freshman returning to the university for their second year were included. Almost all students in all classrooms had made friends in college; most had made friends with peers in the course and were spending time with them outside of class. Compared with LL students, SL reported lower satisfaction with their overall social life. More FC students were satisfied with their social life, and fewer found making friends to be harder than expected. These findings showed even greater disparities between groups for at-risk students. SLM students exhibited lower social integration than CLM students. The CLM flipped classroom retained the highest percentage of students at the university into the second year. Findings from the present study suggest that integrating at-risk students into a first-year seminar flipped classroom that matches student composition of the major benefits social integration and retention into the second year, for all students as well as those with low math scores.

\section{Introduction}

Student retention is often defined as first-time, full-time college students returning to the institution for their second year and is associated with greater student persistence and graduation rates [1]. Nationwide, nearly a third of first-year freshman do not return for their sophomore year and undergraduate 5-year graduation rates are $\sim 40 \%$. Retention of STEM students is especially critical given that attrition rates are higher than their non-STEM peers [2]. Nearly $50 \%$ of bachelor's degree students who entered STEM leave these fields (to other majors or withdraw from higher education) before graduation $[3,4]$. Importantly, STEM attrition occurs more frequently among students with weaker academic backgrounds in STEM-required introductory math courses
[5]. Due to the rigorous scientific coursework that begins in the first semester of the freshman year, undergraduate STEM-based physiology programs are vulnerable to retention-related issues, and physiology freshman with weaker math preparation are especially at risk. Indeed, previous work from our program has found that compared with their peers, freshman with lower incoming math scores transfer out of the major and institution at a higher rate than their peers by their second year (major: low math $61 \%$, high math $34 \%$; university: low math 26\%, high math 9\%) [6]. Therefore, programming specific to incoming freshman with weaker math preparation is warranted to improve retention within the major and university.

Once at an institution of higher education, students' perceptions of the university and students' social fit affect 
their decisions to persist in a program [7]. Social integration reflects the extent to which a student finds the social environment at the university and on campus to be aligned with his or her preferences, often shaped by background, values, aspirations, etc. and can be achieved by developing friendships with peers, finding mentors, or connecting with faculty [8]. The role of social integration in student retention and success is critical $[9,10]$; indeed, successful social integration is associated with greater commitment to the institution or major [11], and previous findings have shown that freshmen transferring out of a STEM-based physiology major report lower social integration [12]. STEM freshman with lower incoming math scores report less favorable responses in areas of social integration (e.g., having fewer friends at the institution and feeling like they have less in common with other students), and more than a quarter of respondents found making friends to be harder than expected [6]. Clearly, increasing social integration for new freshman is critical for retaining STEM students, especially those with lower incoming math scores that are at a greater risk of attrition.

One means of addressing both freshman student retention and social integration is through first-year courses (e.g., first-year seminar or FYS). These courses aid students in navigating their first year of college, including developing life skills and academic strategies and increasing a sense of belonging, and have shown to improve retention and graduation rates [13]. When held within a major, a first-year course offers the opportunity to address retention-related issues (e.g., improving perceptions of student learning, responsiveness of faculty, and accessible advising) on a manageable scale. Classroom design (e.g., class size and teaching modalities) is related to student satisfaction and learning: larger classrooms reduce students' level of active involvement in the learning process and reduces the frequency of student-instructor interaction [14], while flipped classrooms that allow in-class time to be spent working in small groups prioritize student engagement and improve higher-order thinking and knowledge acquisition while building interpersonal skills $[15,16]$. Indeed, restructuring a first-year seminar course to require students to work in small groups, thereby necessitating peer-to-peer interactions, is a proposed means of improving social integration of freshman at risk for attrition [6].

While classroom size and teaching modality have been previously examined, their impact on retention-related social integration of at-risk STEM students in a first-year seminar has not. Therefore, this exploratory study aimed to compare the impact of classroom design on social integration and retention among at-risk STEM students. The primary purpose of this study was to investigate outcomes related to social integration (within the course, major, and university) for the entire class, but especially students at-risk for attrition based on lower incoming math scores (low math), by comparing classroom size (large lecture vs. small lecture), classroom format (lecture classroom vs. flipped classroom), and classroom composition (combined low math with high math students or separation of low math students into a class of only low math students). We hypothesize that the small lecture, flipped classroom, and combined classroom would demonstrate higher social integration of all students, but specifically low math students, at the end of the first semester. The secondary purpose was to determine if classroom designs with higher social integration demonstrated higher retention rates in the major and at the university by the second year, as assessed by longitudinal follow-up.

\section{Methods}

This project was approved by the internal review board at West Virginia University (IRB\#1807211250). Due to the small sample sizes within each classroom, especially for low math students, this study was a largely exploratory, preliminary study that aimed to identify potential differences between classroom design models with the goal of making permanent changes to classroom design for future cohorts.

2.1. Participants. Participants were undergraduate freshman exercise physiology (EXPH) students. This major is largely a prehealth professional, STEM-based program at a landgrant, R1 research institution in Appalachia. All freshmen are required to enroll in a one credit (one hour of in-person class each week over a 16-week semester) freshman seminar course. Much of the remaining coursework taken by freshman in their first semester is largely similar between students (e.g., biology, chemistry, math, and nutrition) because the classes scheduled for their first semester of freshman year are based on the recommended major coursework progression. These courses include students from across the institution, vary in size, and are lecture based except for the laboratory components which are hands-on, experiential learning. While the labs may support social interaction, it would include students from various majors and years (freshman, sophomores, juniors, and seniors) and not necessarily promote social interaction with other firsttime, full-time college freshmen in the major.

To identify at-risk students, an expert panel within the program identified incoming math scores as the best metric to predict student success within the major based on previous findings $[2,5,17]$. In the late summer 2019, incoming freshmen were sorted based on incoming math placement into at risk for attrition (low math) and not at risk for attrition (high math). Those that placed into college algebra or higher (math ACT $\geq 19$ or math SAT $\geq 510$ ) were considered high math, and all others were considered low math. In fall 2019, the 291-student exercise physiology freshman class included $\sim 25 \%$ low math, $\sim 25 \%$ honors (26 ACT or 1230 SAT), and $\sim 50 \%$ that were not low math or honors. Students were randomly allocated into classrooms before the semester started by a blinded third party, an administrative advisor.

2.2. Comparisons. To evaluate the role of classroom design on social integration and retention, this study compared classroom size (large lecture $(100+)$ vs. small lecture $(<50)$ ), classroom format (lecture classroom vs. flipped classroom), and classroom composition (combined low math (21\%) 
with the high math students or separation of low math students into a class of only low math students (100\%)), Figure 1. Classroom comparisons include the following.

2.2.1. Classroom Size. Large lecture (LL, $n=175)$ vs. small lecture (SL, $n=39$ ) were matched for student low math composition ( $15 \%$ low math). This model compared the effects of classroom size on social integration of all students with specific comparisons between low math students in both groups. The LL and SL classes were typical lectures in which the instructor presented information through power point; the LL was held in a large auditorium, and the SL was held in a small auditorium. Each week, the students received identical lectures from the same instructors/guest lecturers. Before the next class period, all students were required to complete a ten-question quiz and homework assignment. Both the quiz and homework were required and counted towards students' overall grade and identical between classrooms.

2.2.2. Classroom Format. Small lecture (SL) vs. flipped classroom (FC) were matched for size (SL $n=39, \mathrm{FC} n=38$ ) and student composition (low math SL: 15\%; FC: $21 \%$ ). This model compared the effects of a SL classroom against a flipped classroom section on social integration of all students with specific comparisons between low math students in both groups. The SL class was a traditional lecture-style classroom in which the instructor presented information from a power point slide show. This in-person lecture was recorded using the learning management system's integrated video platform, Panopto (Seattle, WA, USA). Before the next class period, students in the lecture class were required to complete a ten-question quiz and homework assignment. Both the quiz and homework were required and counted towards students' overall grade and identical between classrooms. For the FC, students were required to watch the recorded presentation and take the ten-question quiz (to ensure they watched the recording) before attending class. The quiz was required and counted towards their overall grade. There were 40 hours between the time the recorded lecture was released to the FC cohort and when their class period started during which they could watch the lecture and take the quiz. In class, students worked in small groups of 5-6 completing the in-class assignments (identical to the lecture students' homework assignments) while the instructor went between groups to facilitate discussion. The in-class assignment was required and counted towards their overall grade.

2.2.3. Classroom Composition. Combined low math (CLM) and separated low math (SLM) FCs were matched for size $(n=40)$. Within the CLM, low math students were integrated into the classroom to match student composition of the major (CLM, 21\% low math), but the SLM was comprised of low math students only (SLM, 100\% low math). This model compared the effects of isolating low math students into an FC that was specific to at-risk students. For the FCs, all students were required to watch the recorded presentation and take the ten-question quiz (to ensure they watched the recording) before attending class. The CLM and SLM class had at least 40 hours between the time the recorded lecture was released and their class period started. In class, students worked in small groups of 5-6 completing the in-class assignments while the instructor went between groups to facilitate discussion. Both the quiz and in-class assignment were required and counted towards their overall grade and identical between classrooms.

The first-year seminar course is taught university wide and overseen by the centralized Center for Learning Advising and Student Success (CLASS). The general curriculum and expected learning outcomes for the course are the same throughout the university, but the specifics and methods of teaching are left to the individual instructor. In exercise physiology, the first 8 weeks are spent preparing students to achieve academic success (e.g., time management, studying techniques, and finding campus resources) while the last 8 weeks are allocated for invited guest lectures to share various careers to pursue with a degree in exercise physiology with the goal of motivating, challenging, and encouraging students to begin to prepare early for the rigors of their chosen postgraduate field. The retention specialist faculty (an assistant professor) was the instructor of record for all sections of the first-year seminar course.

\subsection{Outcomes}

2.3.1. Social Integration Survey. During the last week of classes, all students were invited to complete the Social Integration Survey administered online via Qualtrics (LLC Qualtrics, Provo, UT). This survey aimed to capture student impressions of their first semester as it pertained to social integration as well as select core competencies that could be influenced by classroom design. Course credit was given for completing the survey. The survey included a series of statements to which the students could rate their level of agreement on a 5-point Likert scale (e.g., strongly agree, somewhat agree, neither agree nor disagree, somewhat disagree, strongly disagree; strongly satisfied, somewhat satisfied, neither satisfied nor dissatisfied, somewhat dissatisfied, and strongly dissatisfied). Using skip logic in the survey design, only the FC students answered questions specific to the FC (e.g., Do you feel working in small groups helped you make friends in college?).

2.4. Quantitative Data. Retention rates were calculated from university registrar data of freshman returning to the program and institution for their second year, the start of the fall 2020 semester.

2.4.1. Analysis. Due to small sample sizes, especially in low math groups, all survey responses are presented as percent. For the 5-point Likert responses, the percent of respondents that selected "strongly" and "somewhat" was combined to reflect the percent that confirmed the statement or question. 
For example, all students that selected "strongly agree" or somewhat agree" were combined to confirm that $59 \%$ of the large lecture class enjoyed the format.

\section{Results}

Social integration survey responses for all comparisons are presented in Table 1.

\subsection{Classroom Size (Large Lecture/Small Lecture). Fewer} students (percent) in the SL group felt they were at the right college or in the right major, and these discrepancies persisted in the low math group. Almost all students in both groups had made friends in college by the end of the first semester; most had made friends with other students in the course and were spending time with other EXPH students outside of class. However, the SL students reported lower satisfaction with their overall social life. All low math students had reported making friends in college, and almost all had made friends with other students in the course. However, fewer SL low math students spent time with other EXPH students outside of class and reported lower satisfaction with their social life in EXPH. Compared with the LL class, more of the SL students reported making friends and fitting in was harder than expected, and these findings showed even greater discrepancy in the low math groups. Responses to faculty and course outcomes were generally positive and similar between groups. However, fewer in the LL group enjoyed the format of their class, but this was not seen in low math students.

\subsection{Classroom Format (Small Lecture/Flipped Classroom).} Almost all students in both classes had made friends in college and with other students in the course. Most students spent time with other EXPH students outside of class, but more in the FC were satisfied with their social life in the major and had close friends in the major. All low math students had reported making friends in college and with other students in the course. Compared with low math students in the FC, fewer SLR students spent time with other EXPH students outside of class and reported lower satisfaction with their social life in EXPH. Compared with the SL class, fewer in the FC found making new friends and fitting in was harder than expected, and these findings showed even greater discrepancy in the low math groups. Both groups reported enjoying the format (lecture vs. small group) of the class, but low math students in the FC reported higher enjoyment than those in the lecture class. Compared with the small lecture class more low math students felt the FC helped improve teamwork or leadership skills and oral communication skills (Table 2). Responses to faculty and course outcomes were generally positive and similar between groups. However, despite no differences in enjoyment of the class format, more low math students in the FC expressed favor with the format than the SL low math students.
3.3. Classroom Composition (Combined/Separated). All students had made friends in college, but more SLM students found making new friends and fitting in to be harder than expected. Most students made friends with others in the course and spent time with other EXPH students outside of class. However, fewer CLM students were satisfied with the amount of class interaction with other students in the course. SLM students were less satisfied with their social life in the major. Responses to faculty and course outcomes were generally positive and similar between groups; however, fewer separated low math students felt the course helped them adjust to college.

More of the CLM students felt the course developed core competencies compared with the SLM students (Table 3).

3.3.1. Longitudinal. Transfers out of the major and institution after the first semester and by the second year are presented in Table 4. By the second year, 188 (63\%) students remained within the major while $71(24 \%)$ transferred to a different major and 37 (12\%) left the institution by their second year. Of those that left the institution by their second year, 17 were low math (23\% of low math group) and 20 were high math (9\% of high math group). Across all classrooms, the combined FC not only retained the highest percentage of students at the university into the second year but also saw the highest relative transfer rates (for the whole class as well as low math students) into other majors.

\section{Discussion}

Importantly, since this study spanned from fall 2019 to fall 2020, it occurred during the COVID-19 global pandemic which dramatically altered the college experience during this cohort's freshman year, likely influencing many factors related to freshman retention, including student engagement and academic success. However, overall retention of students from this major to the university at longitudinal follow-up (88\%) was slightly higher than that in previous years $(\sim 85 \%, 2013-2018)$ which aligns with institutional retention rates that increased during the pandemic (fall 2018: 80\%; fall: $201982 \%$ ). The university has attributed this to the fact that academic suspensions were not issued during spring 2020 (e.g., students on academic probation that otherwise would have been suspended). The fall 2019 freshman cohort investigated in this study showed retention rates similar to previous years: $77 \%$ of low math students were retained to the university $(\sim 78 \%, 2013-2018)$ and $91 \%$ of high math students were retained to the university $(90 \%$, 2013-2018).

This study aimed to compare the impact of classroom design on social integration and retention among at-risk STEM students (low math students). The primary purpose of this study was to investigate outcomes related to social integration (within the course, major, and university) for the entire class, but especially students at risk for attrition based on lower incoming math scores (low math students), by 


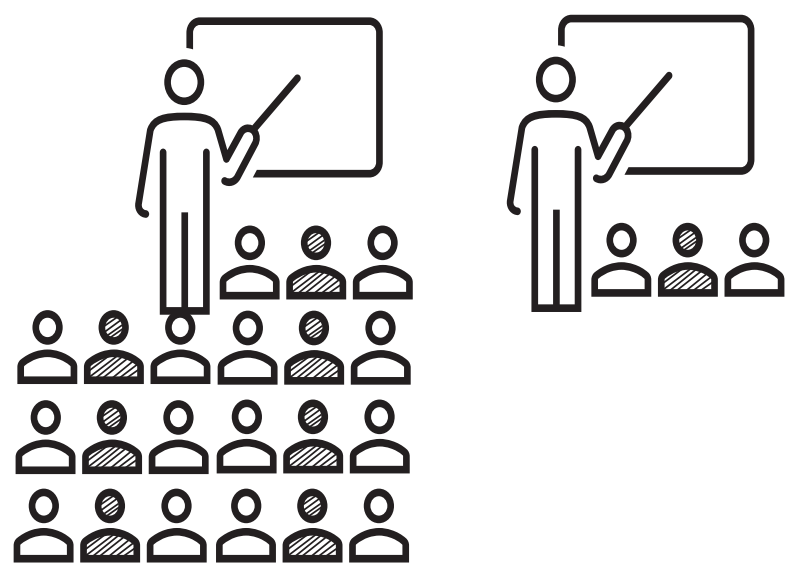

$\frac{\frac{\text { Classroom size }}{\text { Large lecture vs. small lecture }}}{\text { Matched for classroom format and relative proportion of low math students }}$
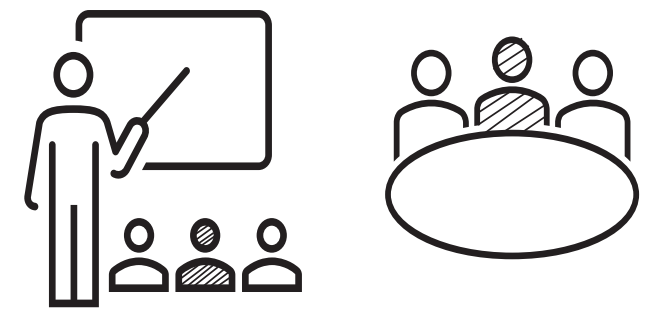

Classroom format

Small lecture vs. flipped classroom

Matched for classroom size and relative proportion of low math students
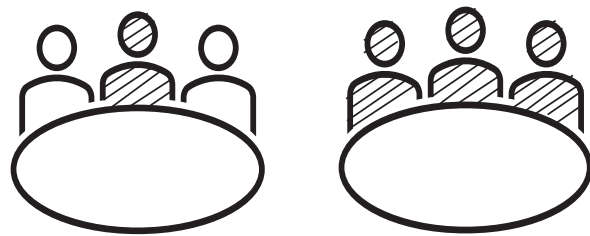

Classroom composition

Combined low math FC vs. separated low math FC

Matched for classroom format and size

Low math student

2 High math student

Figure 1: Classroom design comparisons.

comparing classroom size (large lecture vs. small lecture), classroom format (lecture classroom vs. flipped classroom), and classroom composition (combined low math with the high math students or separation of low math students into a class of only low math students). The secondary purpose was to determine if classroom designs with higher social 
TABLE 1: Social integration survey responses.

\begin{tabular}{|c|c|c|c|c|c|c|c|c|c|c|}
\hline & \multicolumn{4}{|c|}{ Size } & \multicolumn{4}{|c|}{ Format } & \multirow{2}{*}{\multicolumn{2}{|c|}{ Composition }} \\
\hline & \multicolumn{2}{|c|}{ Entire class } & \multicolumn{2}{|c|}{ LM groups } & \multicolumn{2}{|c|}{ Entire class } & \multicolumn{2}{|c|}{ LM groups } & & \\
\hline & LL & SL & LL LM & SL LM & SL & FC & SL LM & FC LM & CLM & SLM \\
\hline Total enrollment & 175 & 39 & $22(13 \%)$ & $6(15 \%)$ & 39 & 38 & $6(15 \%)$ & $8(21 \%)$ & $8(21 \%)$ & $38(100 \%)$ \\
\hline Survey response rate & $\begin{array}{c}123 \\
(70 \%)\end{array}$ & $\begin{array}{c}37 \\
(95 \%)\end{array}$ & $12(55 \%)$ & $\begin{array}{c}6 \\
(100 \%)\end{array}$ & $\begin{array}{c}37 \\
(95 \%)\end{array}$ & $\begin{array}{c}28 \\
(74 \%)\end{array}$ & $\begin{array}{c}6 \\
(100 \%)\end{array}$ & $5(63 \%)$ & $5(63 \%)$ & $24(63 \%)$ \\
\hline \multicolumn{11}{|l|}{ Institution } \\
\hline "WVU is the right college for me" & $93 \%$ & $78 \%$ & $100 \%$ & $67 \%$ & $78 \%$ & $90 \%$ & $67 \%$ & $80 \%$ & $80 \%$ & $83 \%$ \\
\hline I have made friends in college & $98 \%$ & $97 \%$ & $100 \%$ & $100 \%$ & $97 \%$ & $97 \%$ & $100 \%$ & $100 \%$ & $100 \%$ & $100 \%$ \\
\hline $\begin{array}{l}\text { Making new friends and fitting } \\
\text { in was harder than expected }\end{array}$ & $24 \%$ & $46 \%$ & $17 \%$ & $67 \%$ & $46 \%$ & $17 \%$ & $67 \%$ & $0 \%$ & $0 \%$ & $21 \%$ \\
\hline \multicolumn{11}{|l|}{ Major } \\
\hline $\begin{array}{l}\text { "Exercise physiology is the right } \\
\text { major for me" }\end{array}$ & $84 \%$ & $76 \%$ & $83 \%$ & $50 \%$ & $76 \%$ & $66 \%$ & $50 \%$ & $40 \%$ & $40 \%$ & $63 \%$ \\
\hline $\begin{array}{l}\text { Sense of connectedness with other } \\
\text { faculty, students, and staff in exercise } \\
\text { physiology }\end{array}$ & $64 \%$ & $57 \%$ & $75 \%$ & $67 \%$ & $57 \%$ & $62 \%$ & $67 \%$ & $60 \%$ & $60 \%$ & $54 \%$ \\
\hline \multicolumn{11}{|l|}{ Students } \\
\hline $\begin{array}{l}\text { Spends time with other EXPH students } \\
\text { outside of class }\end{array}$ & $78 \%$ & $70 \%$ & $83 \%$ & $50 \%$ & $70 \%$ & $76 \%$ & $50 \%$ & $80 \%$ & $80 \%$ & $67 \%$ \\
\hline $\begin{array}{l}\text { I think I have a great deal in common } \\
\text { with other students in exercise } \\
\text { physiology }\end{array}$ & $68 \%$ & $59 \%$ & $58 \%$ & $17 \%$ & $59 \%$ & $76 \%$ & $17 \%$ & $60 \%$ & $60 \%$ & $58 \%$ \\
\hline $\begin{array}{l}\text { Satisfied with their overall social life in } \\
\text { exercise physiology }\end{array}$ & $73 \%$ & $51 \%$ & $83 \%$ & $33 \%$ & $51 \%$ & $72 \%$ & $33 \%$ & $80 \%$ & $80 \%$ & $58 \%$ \\
\hline $\begin{array}{l}\text { Satisfied with the amount of class } \\
\text { interaction had with the other students in } \\
\text { the course }\end{array}$ & $60 \%$ & $70 \%$ & $67 \%$ & $67 \%$ & $70 \%$ & $79 \%$ & $67 \%$ & $40 \%$ & $40 \%$ & $71 \%$ \\
\hline $\begin{array}{l}\text { I have made friends with other students } \\
\text { in the course }\end{array}$ & $80 \%$ & $84 \%$ & $92 \%$ & $100 \%$ & $84 \%$ & $90 \%$ & $100 \%$ & $100 \%$ & $100 \%$ & $75 \%$ \\
\hline \multicolumn{11}{|l|}{ Faculty/course } \\
\hline $\begin{array}{l}\text { Satisfied with the amount of class } \\
\text { interaction with the instructors in class }\end{array}$ & $70 \%$ & $84 \%$ & $75 \%$ & $100 \%$ & $68 \%$ & $66 \%$ & $83 \%$ & $60 \%$ & $60 \%$ & $58 \%$ \\
\hline $\begin{array}{l}\text { Satisfied with the quality of the } \\
\text { instruction }\end{array}$ & $90 \%$ & $92 \%$ & $83 \%$ & $83 \%$ & $92 \%$ & $93 \%$ & $83 \%$ & $80 \%$ & $80 \%$ & $88 \%$ \\
\hline $\begin{array}{l}\text { Enjoy the format of the class (lecture, } \\
\text { small group, etc.) }\end{array}$ & $59 \%$ & $84 \%$ & $50 \%$ & $50 \%$ & $84 \%$ & $83 \%$ & $50 \%$ & $80 \%$ & $80 \%$ & $71 \%$ \\
\hline $\begin{array}{l}\text { The course helped me adjust to the } \\
\text { college }\end{array}$ & $72 \%$ & $81 \%$ & $83 \%$ & $83 \%$ & $92 \%$ & $83 \%$ & $83 \%$ & $80 \%$ & $100 \%$ & $71 \%$ \\
\hline
\end{tabular}

LL: large lecture; LL LM: low math students in the large lecture; SL: small lecture; SL LM: low math students in the small lecture; FC: flipped classroom; FC LM: low math students in the flipped classroom; CLM: low math students in the combined flipped classroom; SLM: low math students in the separated flipped classroom; data reported as percent positive response (e.g., selected "strongly agree" or "somewhat agree" on 5-point Likert scale).

TABLE 2: Self-perceived improvements in core competencies for classroom format.

\begin{tabular}{|c|c|c|c|c|}
\hline Did this course help you improve your & SL $(\%)$ & $\mathrm{FC}(\%)$ & SL LM (\%) & FC LM (\%) \\
\hline Teamwork or leadership skills? & 54 & 76 & 33 & 100 \\
\hline Oral communication skills? & 32 & 59 & 17 & 60 \\
\hline Written communication skills? & 68 & 79 & 83 & 100 \\
\hline Analytical or critical thinking skills? & 73 & 72 & 67 & 100 \\
\hline Applied problem-solving skills? & 68 & 69 & 67 & 100 \\
\hline Ethical reasoning or decision-making skills? & 76 & 79 & 83 & 100 \\
\hline Ability to innovate or think creatively? & 73 & 76 & 100 & 100 \\
\hline
\end{tabular}

Percent positive response (selected "definitely yes" or "probably yes" on a 5-point Likert scale).

integration demonstrated higher retention rates into the second year, both at the institution and within the major, as assessed by the longitudinal follow-up. The results of this study support the hypothesis that FC and combined classroom would demonstrate higher social integration of all students, but specifically low math students, at the end of the 
TABLE 3: Self-perceived improvements in faculty-identified core competencies for student composition.

\begin{tabular}{lcc}
\hline Did this course help you improve your & CLM (\%) & SLM (\%) \\
\hline Teamwork or leadership skills? & 100 & 58 \\
Oral communication skills? & 60 \\
Written communication skills? & 100 & 38 \\
Analytical or critical thinking skills? & 100 & 54 \\
Applied problem-solving skills? & 100 & 50 \\
Ethical reasoning or decision-making skills? & 100 & 58 \\
Ability to innovate or think creatively? & 100 & 63 \\
\hline
\end{tabular}

CLM: low math students in the combined flipped classroom; SLM: low math students in the separated flipped classroom. Percent positive response (selected "definitely yes" or "probably yes" on a 5-point Likert scale).

TABLE 4: Transfers out of the major and institution.

\begin{tabular}{|c|c|c|c|c|}
\hline & Large lecture & Small lecture & Combined FC & Separated FC \\
\hline Changed major after the first semester & $23(13 \%)$ & $5(14 \%)$ & $7(25 \%)$ & \\
\hline Low math groups & $2(17 \%)$ & $1(17 \%)$ & $3(60 \%)$ & $10(42 \%)$ \\
\hline Changed major by the second year & $36(21 \%)$ & $8(21 \%)$ & $11(29 \%)$ & \\
\hline Low math groups & $5(22 \%)$ & $0(0 \%)$ & $3(38 \%)$ & $13(34 \%)$ \\
\hline Leaving the institution after the first semester & $2(1 \%)$ & $2(5 \%)$ & $1(3 \%)$ & \\
\hline Low math groups & $0(0 \%)$ & $1(17 \%)$ & $0(0 \%)$ & $2(8 \%)$ \\
\hline Leaving institution by the second year & $19(11 \%)$ & $3(8 \%)$ & $2(5 \%)$ & \\
\hline Low math groups & $7(31 \%)$ & $2(33 \%)$ & $0(0 \%)$ & $8(21 \%)$ \\
\hline
\end{tabular}

first semester. The hypothesis that classroom designs that showed higher social integration at the end of the first semester would improve retention rates into the second year for the university was also supported, but not for the majorlevel retention. Additionally, the hypothesis that small lectures, compared with large lectures, would demonstrate higher social integration was not confirmed.

Social integration refers to the interactions between the students and their social system, including informal peer group associations, which can effect student learning and persistence, especially in the first year of higher education [18]. Students who experience a greater degree of social integration at the start of their first year had higher academic motivation at the end of their first year, which facilitates student retention into their second year [19]. Starting college is a transitional phase, and when new students enter a university, they can often feel lonely or homesick, but developing friendships can help freshmen overcome these feelings of anxiety and loneliness [20]. Those that fail to make friends, or spend too much time with previous friends, may be more likely to return home often, thereby becoming more socially isolated at college. In one study, up to three quarters of students leaving the institution discussed the difficulty of making friends in college [20]. Indeed, making compatible friends provides direct emotional support and friendships made through courses are important in providing this social support [20]. Creating an inclusive environment that facilitates peer interaction and promotes social integration can be achieved through smaller class sizes.

In the present study, the authors hypothesized that the smaller classroom would have more favorable outcomes in social integration; however, the findings contradict this hypothesis as students in the small lecture group reported lower satisfaction with their social life in the major (LL 73\%; SL 51\%) and that making new friends and fitting in was harder than expected (LL 24\%; SL 46\%). There were even greater discrepancies between groups in those students at risk for attrition. Perhaps, those in the large lecture had lower expectations for making friends in the course and major because it is easier to feel lost in a large crowd. Indeed, in Appalachia, many students come from very small schools with small class sizes. If starting their freshman year of college in a large lecture, students may assume making friends and fitting in would be challenging whereas students enrolled in a smaller class might have thought it would be easy to make friends (like they could in high school), but by the end of the semester felt less connected to their peers than expected. These preconceived expectations from the start of the semester could be influencing end-of-semester perceptions. Alternatively, all students were in large classrooms in other required courses (e.g., biology), so the large lecture classroom for first-year seminar may have given them a sense of consistency.

However, despite these differences between groups, at longitudinal follow-up, the rates of retention between groups were similar: $11 \%$ of the LL group had left the institution compared with $8 \%$ of the SL group, while $31 \%$ of the LLR group had left the institution compared with $33 \%$ of the SLR group. This suggests that the differences in social integration at the end of the first semester of college between large lecture and small lecture classrooms do not appear to influence whether a student chooses to leave the institution, even for those who come in with lower math scores. Importantly, all students in all groups had made friends in college at the end of the first semester which is likely more influential than social integration in a single course or major.

Interactive class periods, as achieved by flipped classrooms, facilitate peer interaction, social integration, and retention. Indeed, postsecondary students participating in 
cooperative learning in STEM courses demonstrate greater achievement, express more favorable attitudes, and persist through STEM courses or programs to a greater extent than their peers that do not participate in cooperative learning [21]. Generally, our findings support our hypothesis that the flipped classroom would have a positive effect on social integration. While almost all students had made friends in college and within the course, the students in the flipped classroom reported higher social integration at the end of the semester. Specifically, fewer in the FC found making friends and fitting in was harder than expected, and this was mirrored in the low math groups. These findings reinforce the idea that requiring students to interact during the class period facilitates social integration beyond simply "making friends." Especially in those students at risk for attrition, the flipped classroom appeared to have facilitated favorable social integration in the first semester: FC low math students were more likely to spend time with other EXPH students outside of class, had greater satisfaction with their social life, and felt they shared things in common with other students in the major. Flipped classrooms allow in-class time to be spent working in small groups facilitating peer-to-peer interactions and building interpersonal skills $[15,16]$ which improves social integration of freshman.

Compared with a small lecture, the flipped classroom students reported improvements in teamwork/leadership and oral communication skills. This is an often-seen advantage to flipped classrooms: they help build these critical interpersonal skills $[15,16]$. Low math students seemed to prefer and benefit from the flipped classroom format. Interestingly, almost all CLM students reported improvements in core competencies with lower reported self-improvement in the SLM students. Perhaps, integrating low math students into the general classroom with higher-placed peers facilitates beneficial interactions that improve core competencies. As an exploratory study, the role of classroom design on core competencies was insufficiently investigated but offers promise as a potential area of future research, both for the impact on the course outcomes and programmatic outcomes.

These benefits appear to persist in retention rates at the longitudinal follow-up: 3 (8\%) of the SL and 2 (5\%) of the FC left the university by their second year, while 2 (33\%) of the SL low math had left compared with $0(0 \%)$ FC low math. Though seemingly a small difference, retaining even one or two extra students from this major to the university meets the university-wide student retention five-year target of $85 \%$. More importantly, those few individuals retained will graduate and enter the workforce with a college degree.

When low math students were either integrated into the classroom to match student composition of the major (CLM, $21 \%$ low math) or isolated into an identical FC that was comprised of low math students only (SLM, 100\% low math), it appears integrating was more beneficial for social interaction. In fact, no student in the CLM group felt making new friends and fitting in was harder than expected. The benefits of integrating low math students into a classroom that matched student composition of the major may benefit long-term retention. At one-year follow-up, 0 students from the combined classroom had left the university, but $21 \%$ $(n=8)$ had left from the SLM group. Interestingly, across all classrooms, the combined flipped classroom not only retained the highest percentage of students at the university into the second year but also saw the highest relative transfer rates (for the whole class as well as low math students) into other majors. This important finding could be because the low math students interacted with students that were more academically prepared for a STEM major and realized these discrepancies, prompting them to pursue less rigorous majors. Perhaps, they were unnecessarily intimidated and left the major even though they might have ultimately been successful. However, since students' reasons for transferring were not captured, this remains an important potential area of future research for physiology programs that want to facilitate social integration of all students and improve retention to the major as well as the university.

Social integration into university life can be achieved not only by developing friendships with peers but also by connecting with faculty and finding mentors [8]. Both formal in-class interactions with faculty and more informal student-faculty contact can benefit students' social engagement. Although this was not a primary outcome of the present study, there were no differences between groups in satisfaction with the amount of class interaction with the instructor or the quality of the instruction. These null findings confirm that changing the classroom design does not negatively impact the perceptions of faculty engagement. Furthermore, it could support our postulation that the positive social integration findings seen in the present study are driven by peer-to-peer interaction in the classroom.

There were several limitations to this study. First, as described previously, the longitudinal follow-up was influenced by the global COVID-19 pandemic, but any effects of the pandemic on retention rates were not investigated. Furthermore, it was conducted on a specific cohort of exercise physiology freshman at a large, 4-year public institution in Appalachia. While the generalizability of these findings to other institutions may be limited, the study and findings may help inform future research in this field and region. To ensure the proportion of students in the smaller classrooms were reflective of the overall major, there were small low math sample sizes in the small lecture and flipped combined classroom, and the survey questions used in this study were not validated; therefore, the wide application of these findings should be cautioned. However, as this was an exploratory, the findings are relevant to the development of future support programs within this major and will guide retention efforts moving forward. Many factors that contribute to retention and social integration were not evaluated in this study. Importantly, the wider social world of the university impacts students' lives more than a single academic classroom. For example, in one study, making friends through living arrangements was more significant for social integration [20]. Furthermore, students were randomly assigned to classrooms, but this is not uncommon in college as a traditional lecture format vs. flipped classroom is decided by the instructor or program unit. Attendance was not tracked; however, since the assignments that were submitted during the in-person class counted towards students' final grades, it was likely the FC improved attendance. 
Despite its limitations, this exploratory study presents novel findings on first-year retention within a physiology major. The randomized allocation of students and careful controls employed (same content, content delivery, lecturer, activities, etc.) provides important comparisons investigating the effect of classroom design on retention and social integration of freshman physiology students. Future research should include larger datasets over multiple cohorts to more fully elucidate the impact of these classroom settings.

\section{Conclusions}

This study successfully compared the impact of classroom design on social integration and retention among at-risk STEM students (low math students). Findings from the present study suggest that integrating low math students into a first-year seminar flipped classroom that matched student composition of the major benefits social integration and retention into the second year, for all students as well as the low math students.

\section{Data Availability}

All datasets used and/or analyzed during the current study are available from the corresponding author on reasonable request.

\section{Conflicts of Interest}

The authors declare no conflicts of interest.

\section{Authors' Contributions}

ML and RB conceived the work. ML, AL, and VC collected the data. ML and RB interpreted the data. ML drafted the manuscript, and all authors reviewed and approved the final work.

\section{References}

[1] H. Program, Degrees of Success: Bachelor's Degree Completion Rates Among Initial STEM Majors, Higher Education Research Institute, Los Angeles, CA, USA, 2010.

[2] X. Chen, STEM Attrition: College Students' Paths into and Out of STEM Fields. Statistical Analysis Report. NCES 2014-001, National Center for Education Statistics, Washington, DC, USA, 2013.

[3] X. Chen, Students Who Study Science, Technology, Engineering, and Mathematics (STEM) in Postsecondary Education. Stats in Brief. NCES 2009-161, National Center for Education Statistics, Washington, DC, USA, 2009.

[4] H. Institute, Degrees of Success: Bachelor's Degree Completion Rates Among Initial STEM Majors, HERI Report Brief, Los Angeles, CA, USA, 2010.

[5] E. Seymour, Talking about Leaving: Why Undergraduates Leave the Sciences, University of Colorado, Boulder, Colorado, 1997.

[6] M. Leary, A. Morewood, and R. Bryner, "A controlled intervention to improve freshman retention in a STEM-based physiology major," Advances in Physiology Education, vol. 44, no. 3, pp. 334-343, 2020.
[7] G. D. Kuh, J. L. Kinzie, J. A. Buckley, B. K. Bridges, and J. C. Hayek, What Matters to Student Success: A Review of the Literature, National Postsecondary Education Cooperative, Washington, DC, USA, 2006.

[8] W. Scott Swail, A. A. Cabrera, C. Lee, and A. Williams, Latino Students and the Educational Pipeline, Part III: Pathways to the Bachelor's Degree for Latino Students, Virginia Tech, Blacksburg, VA, USA, 2005.

[9] C. Demetriou and A. Schmitz-Seiborski, "Integration, motivation, strengths, and optimism: retention theories past, present, and future," in Proceedings of the 7th National Symposium on Student Retention, The University of Oklahoma, Norman, Oklahoma, May 2011.

[10] V. Tinto, Student Retention and Graduation: Facing the Truth, Living with the Consequences Occasional Paper, Pell Institute, Washington, DC, USA, 2004.

[11] J. P. Bean, "The application of a model of turnover in work organizations to the student attrition process," The Review of Higher Education, vol. 6, no. 2, pp. 129-148, 1983.

[12] M. Leary and R. Bryner, "An exploratory study of freshman attrition from an appalachian physiology program," Advances in Physiology Education, vol. 45, pp. 501-510, 2021.

[13] T. Cambridge-Williams, A. Winsler, A. Kitsantas, and E. Bernard, "University 100 orientation courses and livinglearning communities boost academic retention and graduation via enhanced self-efficacy and self-regulated learning," Journal of College Student Retention, vol. 15, no. 2, 2014.

[14] J. Cuseo, "The empirical case against large class size: adverse effects on the teaching, learning, and retention of first-year students," The Journal of Faculty Development, vol. 21, no. 1, pp. 5-21, 2007.

[15] N. Davidson and C. H. Major, "Boundary crossings: cooperative learning, collaborative learning, and problem-based learning," Journal on Excellence in College Teaching, vol. 25, 2014.

[16] J. H. L. Joyce Hwee Ling Koh, "Four pedagogical dimensions for understanding flipped classroom practices in higher education: a systematic review," Educational Sciences: Theory \& Practice, vol. 19, no. 4, pp. 14-33, 2019.

[17] K. Hefling, "The "moneyball" solution for higher education," Politico Pro. Retrieved June 14 from https://www.politico.com/ agenda/story/2019/01/16/tracking-student-data-graduation000868 ? utm_source=MOUNTAINEER+ENEWS\&utm_cam paign=31fe465ac3-EMAIL_CAMPAIGN_2019_01_25_07_ 55\&utm_medium $=$ email\&utm_term $=0 \_02$ ac3f $7274-31 \mathrm{fe} 4$ 65ac3-145300277, 2019.

[18] A. Nevill and C. Rhodes, "Academic and social integration in higher education: a survey of satisfaction and dissatisfaction within a first-year education studies cohort at a new university," Journal of Further and Higher Education, vol. 28, no. 2, pp. 179-193, 2004.

[19] D. Noyens, V. Donche, L. Coertjens, T. Van Daal, and P. Van Petegem, “The directional links between students' academic motivation and social integration during the first year of higher education," European Journal of Psychology of Education, vol. 34, no. 1, pp. 67-86, 2019.

[20] P. Wilcox, S. Winn, and M. Fyvie-Gauld, "“It was nothing to do with the university, it was just the people": the role of social support in the first-year experience of higher education," Studies in Higher Education, vol. 30, no. 6, pp. 707-722, 2005.

[21] L. Springer, M. E. Stanne, and S. S. Donovan, "Effects of smallgroup learning on undergraduates in science, mathematics, engineering, and technology: a meta-analysis," Review of Educational Research, vol. 69, no. 1, pp. 21-51, 1999. 